\title{
SECOND-GENERATION AMERICANS
}

\section{By Rosa Schreurs JENNINGS}

In his home at Cedar Falls, Iowa, in 1890, my father, G. Schreurs, born Gerrit, in Enschede, Holland, renamed George by the Dutchman who employed him on his arrival in America, signing himself $G$. as a compromise, faced his wife Elizabeth Menkens Schreurs in angry excitement. He'd had his last clash with a certain heckling straw-boss in Miner's Flour and Feedmill; he had quit his job. The shocked amazement in Bette's face made him angrier still. She ought to know there were limits to a man's ability to take from an unlettered fellow-workman what he had taken for years, mostly because he had been born a foreigner! True, he could have gone to the "old man", Mr. Miner, himself. But that just isn't done. So he was out of a job.

The Schreurs family in Holland had had considerable land at one time, and always in the background of Gerrit's mind since coming to. America had been the hope to get on a farm of his own some day. Bette was not enthusiastic; yet she knew Gerrit's trigger-temper personality could not much longer endure taking orders from others. He needed to be "his own boss". So they bought an 80-acre farm in Butler county, Iowa, for $\$ 2,300$, placing a mortgage of $\$ 1,800$ against it. Three hundred bushels of the current corn crop went with the sale, also millions of cockleburs and wild morning glories. The land was excellent.

Shall I ever forget that mortgage figure and its accompanying $\$ 126$ for the annual interest at seven percent? They were to hound us and haunt us for years. In September we moved to the farm. Friendly neighbors hauled seven wagon loads of furniture by team the seventeen miles from Cedar Falls to Swanton, Iowa, which was to be our postoffice address until rural free

* An epilogue to Mrs. Jennings' moving life story of her foreign-born parents, "A Scrap of Americana," ANNALS of IowA, Vol. XXIX, No. 4, pp. 290-297. 
delivery displaced that service. Rain that night nearly ruined a lot of books in a load left outside. It would be a long time before much money could again be spent for books; the main plank in the Schreurs platform of household economy for most of the next decade was to be, "Make it do, or do without".

\section{STOCKING THE FARM}

Things had to be bought for the farm, however. Father bought cows at a farm sale some fifteen miles away, and my brother Henry, aged twelve, went along to help drive them home. His help included "twisting the cow's tail", no unimportant aid in getting one most reluctant lady to Swanton. Cows weren't new to us; we had one in Cedar Falls, and my brother and I had driven her to pasture for several seasons. What a wonderful way driving the cow to pasture provided for Henry to escape to a long summer's day of swimming and baseball, with the danger, always, that the Cedar river would claim one more victim of drowning. But our Jersey was gentle and docile; this cow "kicked like a horse" the men said. She ran away the next day; we found her after considerable search, and she settled down to a humdrum life away from Butler Center, the county one-time metropolis where father had bought her. Butler Center was losing some of its human population, too; Allison had won out in a better contest for location of the county seat.

It was muddy in our barnyard, and father thought the wooden shoes which creamery men wore at work would be good; he had worn them as a little boy in Holland, too. However, the wooden-shoe experiment didn't last long. Trying to shut up a sow about to become a mother proved the need for footwear more elastic than wooden shoes. Perhaps the sow enjoyed foiling mere man's effort, perhaps she was mad like father; when, after an hour's futile chasing, she ran between father's legs and knocked him down, Henry and I were helping get out of sight where it was safe to laugh. 


\section{Fighting the Farm Pests}

The cockleburs were popping open day by day, and it fell to Henry and me and six-year-old Elizabeth to pull and gather the stalks in an effort to clean out that weed. In the spring we pulled baby plants, also morning glory and bind-weed. Father licked those cockleburs, but they weren't dead; they had dug themselves deep into our souls.

A pleasanter task was picking up apples, great, pindot-speckled, red Hass with snow-white pulp and pink lining just under the skin, and flavorful, yellow, pointed sheep's-nose. We stuffed ourselves all fall on firm, juicy apples, and ate dried-apple pie in the winter from the sackful that mother dried. In case you have forgotten, or never knew, putting up a big sack full of dried apples takes a bit of doing.

Pasture was short, and father turned the cows on the meadow, which entailed watching them lest they get into the corn. The fall school vacation was a month long, and I spent most of that time with the cows. How describe that month? Throw together, in the hush of Indian summer, warm, golden sunshine, browning corn stalks, purple iron-weed, red clover enticing still a belated bumble bee, all under a sky of gentian blue, flecked with fleecy clouds. Around it-distance. My Youth's Companion lay neglected; inaction had here a pleasure all its own.

But when our cream check was due there was none; the creamery had failed. The one to which we next sent our milk "went broke", too. And, grinning with Mephistophelian glee, around the corner lurked the bank failures, depression, drought, and hog-cholera epidemics of the early 90's.

\section{CoRn Picking ON THE "Down Row"}

Father was left-handed, so he put the bang boards for corn picking on the left side of the wagon, and he wanted the horses astride a row of corn which meant a down- 
row to clean up. I had the down-row; father took two rows next the wagon; and Henry had the third. With my row went aching back, lame wrist-farmers still used the old-fashioned husking peg, and I just couldn't learn to use less than three, sometimes four motions to each ear of corn-and blisters; with father's went occasional clouts on the head from a hard ear of "calico" corn, due to Henry's right-handedness. Our combined efforts yielded two loads a day, about 80 bushels.

Father enjoyed one advantage over his neighbors, who, naturally, were amused at our slow picking; he could shovel off his load with ease, for his years at Miner's mill had included a lot of shovelling. Our neighbors made as much work of the shoveling as they did of the picking.

What appetites we developed! And what good food mother prepared! That and the endless patching of husking gloves were her contribution to the corn harvest. Little Elizabeth came out in the middle of each half-day with cookies and a drink, and picked up loose ears of corn, for, like Ruth of old, we gleaned the fields very closely that year. We finished on Thanksgiving Day in snow and sleet and mud.

Our leisurely picking, as I look back at it in retrospect, carried with it one thing of inestimable value. As children of a ten-hour-day, six-day-week working-man we had seen our father most when he was tired, except on Sundays and particularly one glorious Sunday each fall when we went up the Cedar river by boat to gather wild grapes from which father made most excellent wine, and mother made grape jelly. Coming home under a "Hunter's Moon" was sheer ecstasy. And there in the corn field we learned to know father better-his ancestry and early life in Holland, his hatred of the monotonous grind of the cotton mills where he was employed, his love of America, and his hopes for us.

Within a few years higher bang boards went up on the right side, and the down-row was abolished; next father and I worked by ourselves. Henry, who was to 
develop into one of the then fast pickers able to harvest from 90 to 100 bushels a day, worked alone. I became able to pick about 50 bushels a day, and helped even after I was teaching in rural schools, because paying for corn husking took such a big chunk out of a farmer's income. Henry, after we were through, earned a nice sum of money picking out, more than my fall term of school brought me.

\section{DRUDGERY OF THE KITCHEN FLOOR}

Often, today, when I am doing the simple job of wiping the linoleum floor in my kitchen, I think back to our soft-pine kitchen floor of that early time, and I am inclined to believe that the invention of linoleum has been the greatest boon of all to women. On Saturday night when the rest of the family were bathed and in the living room or bed, mother and I scrubbed that floor with broom and hot, sudsy lye water-too much lye made it red, though. We swept the dirty water out through the open door, rinsed with more hot water, swept that out, then mopped the floor dry. Steam filled the room, especially in winter time.

On Sunday morning a beautifully white floor began the new week for us, a new leaf, as it were, soon, like other new leaves, to be spotted with the grime and dirt of daily living. Mother scorned a mid-week mopping that would eventually make the boards grimy, which, Dutch-born housewife that she was, she could not endure. I must admit mopping would have been wiser, for by Saturday we actually dreaded having company drop in; in spite of carpet strips that floor was really dirty. While we were still "hard up" father put in a new one of hard wood, which later was painted then the mopping sufficed.

I usually went after the mail which came twice a week to Swanton from New Hartford. That was a long time to wait for yellow fever news! The post office was a mile and a half away, so it took a three-mile walk twice a week to keep up with current events. The walk wasn't 
too hard; some of the school children walked that far, and walked it every day. We had to go only a few rods, for the schoolhouse stood on the corner half-acre of our farm, an item very important to father when he considered buying the land. I'm quite sure that the rural school has been slandered; many outstanding men learned their three R's and other sterling values in some little white (all that I remember were white) schoolhouse.

$A$ visit from an itinerant peddler was always exciting, especially if he stayed overnight. A tin peddler sold us a water dipper having a copper inset in the middle of a tin bottom which, he said, would keep it from rusting. It did, too, and, heedless of the germs just coming into public eye, we used that dipper for years. From a drygoods peddler mother bought her unbleached Irish-linen table cloths and Irish-linen lace for trimming.

\section{ORganized ReLigIOUS ACTIVITY}

One day a young student missionary, Wm. B. Sanford, from the state of Connecticut, working for the American Sunday School Union of Philadelphia, came to our house; he was made welcome for as often as he chose to come after that. There was no Sunday school in the neighborhood; we couldn't always get across the river to Coster, six miles away, where we had affiliated with the Evangelical church, and Mr. Sanford's initial visit marked a mile-stone in our lives. The Sunday school he organized under the auspices of the American Sunday School Union expanded, some years later, into a branch of the Congregational church at Parkersburg, which Mr. Sanford, then ordained as minister, was serving. Many "stood on the mountain tops" that day, and, as always, came down to the mundane task of raising funds.

The women turned their hands to everything to make money: ice cream socials, entailing hours of turning freezers by hand; but, oh! such ice cream accompanied by delicious cakes and mother's matchless biscuits; basket auctions with their not always good-natured rivalry, especially if the lady had slyly indicated to her swain some 
distinguishing mark; quilting at a dollar a spool of threadquilting as an art, however, was dying out; sewing carpet rags at five cents a ball-that, too, was on the way out; even cleaning the school house for three dollars each cleaning, once a year at first, later, as public consciousness of health developed, twiec a year.

We came together, too, in community "sings"; those who didn't sing played crokinole or caroms. Our church organization held together nearly ten years, then dissolved as rural organizations so often did with change of residents. Sporadic Sunday school and church services were held there after that; today the automobile makes town membership easy. Mr. Sanford went to Des Moines where he served as pastor of Westminister Presbyterian church from 1905-1915, then to Philadelphia where we lost touch with him. He died in Florida not long ago.

Our reed organ which we had brought from Cedar Falls attracted much favorable notice, and soon several others came into the neighborhood. Father offered that I who had had several terms of lessons give lessons free to the two daughters of a fellow-countryman who had bought an organ. Once a week I stayed over night with them, giving each girl a lesson an hour long before we went to bed. Then we talked and giggled until the early hours of morning, only going to sleep when the final thump of their irritated father's fist on the wall carried a special note that this was the last warning. Later I gave quite a few lessons for pay, walking across the fields to reach the road a mile away. In one case it was a housewife with little time to practice, but we had grand visits together; in another the boy's mother kept watch that we didn't idle any time-she wanted culture for her boy, but also her twenty-five cents worth, full value received. Luckily, a real music teacher who charged real prices appeared, and I no longer transgressed musical and pedagogical laws and traditions. 
Poignant memories of that organ, replaced years ago by a piano, come to me: of father, singing lustily on Sabbath mornings; of the sister who learned to play very well, whose arthritic hands now deny her that pleasure; of community sings; of a visiting immigrant boy who knew all the best operas because admission prices in Europe were cheap-how he loved to sing them in this strange, new land; of songs of the 90's, some gay, some sad, all sentimental.

To the State Normal School

Father had promised early in 1893 that if hogs reached seven dollars I might go to Iowa State Normal school to prepare for teaching. Hogs didn't reach that price; hard times and a drought were on, but the family decided that I should still "go to the Normal". (None of us got to Chicago, though, to visit the fair; there wasn't any money for that.) I had no high school credits for matriculation and entered on a second-grade teacher's certificate obtained by taking an examination in Allison, Iowa. We drove to Cedar Falls in our open two-seated buggy-it was several years more before we achieved top-buggy status-in heat and wind an dclouds of dust. Enrollment came the next day.

The buildings consisted then of North hall and South hall lately connected by a roughly boarded, two-story, enclosed bridge built for a double purpose, to keep back the bitter sweep of wind from the west, and to shorten the distance between class rooms. Students found in it wonderful trysting places, but I S N S students had to walk a very straight and narrow way in those daysno smoking, no dancing, no petting, no rough talking. A highly religious and moral atmosphere pervaded the school.

In the spring of 1894 I began my first term of teaching. All three of us were to take a turn at it-Elizabeth's two daughters later carried on the tradition. All three of us were to attend college, for shorter or longer periods, as were Elizabeth's children and mine. Henry had no children. 
Henry and father disagreed so completely over the newer ways of farming that they could no longer work toether with any degree of satisfaction. Henry tried a number of things, working out as hired hand, clerking, teaching, selling books-an epidemic of agents had hit the country, organ agents, book agents, sewing machine agents, orchard agents. Taking orders was easier than collecting on delivery, and we housed a dozen or so of his unclaimed copies of "Portraits and Principles", Christmas and graduation gifts to-be for unwitting friends.

\section{LIFE'S DUTIES For EACH}

Came the turn of the century. About our later lives? For Henry the field of pharmacy, and long service in the navy as pharmacist and hospital steward; for Elizabeth teaching, then farming with eventual ownership of the old home in Swanton-what a difference electricity has made; for me life-long teaching. There are three of the third generation (one died in early manhood), six of the fourth.

Robert, of the fourth generation, reading "A Scrap of Americana" on the floor in front of the oil-burner, which now takes the place of the hard coal base-burner of the 1890's, says to his grandmother Elizabeth Schreurs Perrin, "But why does it stop when it is still interesting?"

So stopped G. Schreurs' life at seventy, still interesting. They had moved to New Hartford, Iowa, where he occupied himself with garden, church, reading, town gossip, and a considerable part of the housework, for Bette was an invalid now. He had prepared on Saturday night with bible, encylcopedia, and dictionary the Sunday school lesson he never taught; he was stricken in church the next day. It was ten years before we could fold mother's hands, once so busy, long idle from the ravages of paralysis and pain, and whisper to each other, "He giveth His beloved sleep". 
They lie in Oak Hill Cemetery just outside of New Hartford, oblivious of storm and sunshine, deprivation and plenty, and pain. But I like to think they know that they sleep in the land of their early dreams and hopes, America, and know, too, that their children and children's children enjoy in that same dear land the blessings of liberty in law.

\section{"IOWA THE BEAUTIFUL"}

\section{Arrangement by L. C. Bowers* \\ Air: "America the Beautiful"}

Our Iowa, dear Iowa, a hundred years of life;

A century of hopes not fears;

Of peace and war and strife;

Oh Iowa, loved Iowa, what progress she has made;

Her men who toil, who till the soil;

Of nothing are afraid.

Oh Iowa, our Iowa, a commonwealth supreme;

Proud of her fields of corn she yields;

Rich as a poets dream;

Our Iowa, loved Iowa, formed by the hand divine;

Mend all our flaws; obey our laws;

And all our deeds refine.

Oh Iowa, our Iowa, with wealth in herds of swine; Of hams and chops, and garden crops;

And fruits of many kind;

Oh Iowa, our Iowa, with blessings all supreme;

And crown thy good with brotherhood;

From stream to shining stream.

Oh Iowa, dear Iowa, with milk from lowing kine;

Such liquid gold will strength unfold;

Best food for man or swine;

Oh Iowa, our Iowa, with blessings all supreme;

There's good in every neighborhood.

From stream to shining stream.

Oh Iowa, fond Iowa, her youth's united band;

Her boys and girls in 4- $\mathrm{H}$ Clubs;

Head, Heart and Health and Hand;

Oh Iowa, fond Iowa, God keep them as they grow;

Stay near their side and there abide;

Their path of duty show.

* Dedicated by Mr. Bowers, to the Centennial of Iowa's admission to the Union, on December 28, 1946. 
Copyright of Annals of Iowa is the property of State of Iowa, by \& through the State Historical Society of Iowa and its content may not be copied or emailed to multiple sites or posted to a listserv without the copyright holder's express written permission. However, users may print, download, or email articles for individual use. 